Amany Abdullah Abdel-Aziz El-Diasty

\title{
Grim Culture Vs. Wild Nature: An Ecocritical Perspective of Nathaniel Hawthorne's The Scarlet Letter
}

Amany Abdullah Abdel-Aziz El-Diasty

Lecturer, Faculty of Arts, Damietta University, Egypt.

\begin{abstract}
Though a concern with nature is one way of accessing the fictional world of all Hawthorne's Transcendentalist contemporaries, he has long been considered the least interested in nature. Despite the vast research done on Hawthorne's rich and multilayered novel, The Scarlet Letter (1849) has been overlooked ecocritically. Naturel Culture dichotomy is being overlooked in Hawthorne's work. The goal of this paper is to advance an understanding of Hawthorne's attitude towards Culture/Nature dichotomy through rereading The Scarlet Letter and to derive ethical concepts out of nature. To convey his ecological vision, Hawthorne juxtaposes wild nature against the city of Boston and all that the urban culture stands for in 1750. Through the pastoral experience of Hawthorne's heroine, he rediscovers the natural landscape his ancestors once possessed and discarded as a secluded location of secret desires and moral absence. Exploring the interdisciplinary nature of Ecocriticism to the pastoral mode permits a reconsideration of nature/culture relationship. Hawthorne employs his pastoral heroine to resolve the root tensions between culture and nature by living in the borderline between them, gaining wisdom through her long years of solitude. Connecting the interdisciplinary nature of ecocristicsm together, the paper shows that the values expressed in the text are consistent with the ecological wisdom through psycho-analyzing Hawthorne's main characters. Hawthorne, as a green writer, seeks to promote a reconsidering of one's beliefs and one's vision of Nature for a sound awareness and an essential unity of life.
\end{abstract}

Key Words Ecocriticism, nature/culture, town/wilderness, solitude, pastoral, consciousness, Scarlet Letter

As a field of literary inquiry, pastoral or ecological criticism emerged in the last two decades, and it appeared in no small part through the work of nineteenth-century Americans like Lawrence Buell, Michael Branch, Thomas Lyon and many others. Ecocriticism is an interdisciplinary approach that is famously defined and much quoted as "study of the relationship between literature and the physical environment (Cheryll Glotfelty xviii)". Studies and scholarships in this literary field have been noticeably slow to recognize how cultures share or fight over nature or the wilderness. Nature/ Culture duality generates a philosophical problem in the sense expressed by Levi-Strauss. In his book The Savage Mind (1962) Levi-Strauss, the French anthropologist, writes on the debate between culture and nature, confirming that there are "only two true models of concrete diversity: one of the plane of nature, namely that of the diversity of species, and the other on the cultural plane provided by the diversity of function" (124). Culture is "a social 
construct" while nature is separately functioning as an entity. His writings denote that women could be assimilated to nature and men to culture. Strauss shows culture's domination over nature.

A decade later comes Sherry Ortner tracing a Levi-Straussian footstep of the relationship between culture and nature, stating that nature and culture are both categories of the human thought because "there is no place out in the real world where one could find some actual boundary between the two states or realms of being" (73). Ortner defines culture as the product of the human consciousness; by means of systems of thoughts humanity seeks to assert control over nature (73). Her work suggests that both nature and culture are human constructs. However, in What is Nature?(1995) Kate Soper differentiates between "shallow nature" and "deep nature". The former, relevant in this context, denotes the nature of our immediate experience of everyday life including animals, our bodies, the natural environment, and material resources while the latter refers to the condition for any human intervention in the environment or the biological realm (15-16). In Second Nature (1999), Michael Pollan indicates that American writers have a deeply entrenched habit of seeing nature and culture as inherently opposed (74). This deeply entrenched habit is relevant to part of Hawthorne's stance in The Scarlet Letter, as this paper is trying to show.

Despite two centuries of extensively academic research on Scarlet Letter (1849) — Hawthorne's finest and perhaps most important - the novel has been overlooked eco-critically. The goal of this paper is to advance an understanding of Hawthorne's attitude towards Culture/Nature dichotomy through rereading The Scarlet Letter and to derive ethical concepts out of nature. This paper is also trying to argue that in The Scarlet letter, Hawthorne struggles to rediscover the natural landscape that his Puritan ancestors once possessed and discarded as a secluded location within which lie the powers of darkness. The hypothesized relationship between Nature/Culture is one of antithesis, yet the paper will show an emotional connection with the natural world through Hawthorne's depiction of the main character. Hawthorne's heroine, Hester, gains some moral and esthetic beliefs and realizes a more fruitful fashion to live with the land.

Being one of the most important 19th century American Transcendental writers, Hawthorne rejects Transcendentalism on the grounds that they consider nature to be "man's true home". Unlike Emerson - the leading exponent of Transcendentalism-who talks about 
the mystical unity of nature, urging his readers to "enjoy an original relation to the universe," Hawthorne attempts to meddle with the great forces of nature. He makes fun at his contemporary Transcendentalists in "Custom House", an introductory part that sets the tone of his novel, referring to them as his "dreamy brethren of Brook Farm...indulging [in] fantastic speculation besides our fire of fallen boughs" (23). He was haunted by the New England Puritan culture through his familial connections. His grandfather Colonel John Hathorne was involved in the Salem Witch Trials without feeling remorse for his participation. Hawthorne's The Scarlet Letter (1850) takes place in 17th century grim Puritan Boston but is presented through the perspective of a 19th century New Englander. Set in Boston, it exposes the hypocrisy of the Puritans at that time.

Hawthorne views the Culture in Boston as distortions whereby priests and religious men do not practice what they preach. In portraying the sinful relationship between the minister and his parishioner, Hawthorne depicts Dimmesdale as the supposedly ideal Puritan in contrast to Hester, the sinner. Dimmesdale rejects the notion of openly confessing his sin because he is afraid of public scorn and shame; he cannot endure public exposure. Hawthorne observes all around him with a keen eye and a philosophical spirit, describing the ordinary but remarkable events and people he encounters in the natural world. Though Hawthorne has long been considered by many critics to be the least interested in nature, this paper shows that a considerable concern with nature is one way of accessing Hawthorne's contemporary Transcendentalists' work. In Scarlet Letter, he documents his keen observations on his grimly oppressive Puritan Culture and at one time he discusses the meaning of living in harmony with Nature and one's soul while at other times he shows Nature as wild and autonomous through his language and representation of the nonhuman world.

In Scarlet Letter, Hawthorne depicts the story of Hester Prynne, a woman who goes against what her Puritan culture says is right. She stands up for what she believes in and ends up sinning with her Pastor Reverend Arthur Dimmesdale. The Puritan Culture shames her and she is to eternally wear a scarlet A upon her bosom as a sign of her guilt and punishment for her sin of adultery, and the Puritan authorities sentence her for seven years. The central characters have committed a sinful act which is considered a crime against the Puritan laws, yet this act is not necessarily a crime in the eyes of nature. To sharpen the antithesis 
between Culture and Nature, Hawthorne starts the novel with a lengthy natural description through juxtaposing two scenes telling the readers that "[t]he founders of that colony [...] have recognized it among their earliest practical necessities to allot a portion of the virgin soil as a cemetery, and another portion as the site of a prison" (42). It is as if he wants to say that there are two inevitable facts in the grim Puritan culture, death and human frailty: death necessities burial and human weakness jail.

Against this grim cultural manifestation of Scarlet Letter, Hawthorne describes the natural setting. Beside the threshold of the prison's door, a sign of grim culture, there stands a wild rose-bush. To the sinner who goes in or out of the prison, it is "a fragran[t] and fragile" reminder that beauty and splendour still exist; for the "condemned criminal as he come[s] forth to his doom, "the sight of the delicate petals is a reminder of Nature's pity and sympathy for him/her (Hawthorne 43). The living wild rose bush, "the graceful plant of Muses" (Ferber 173), foreshadows the emergence of the courageous lover who defies the Puritan culture; it is a metaphor of Hester Prynne since the rose is wild to keep with the defiant nature of the heroine. Hawthorne introduces an element of Nature, a rosebush, to offer a glimmering ray of hope to all who feel hopeless and condemned in the grim Puritan Culture. Here, Hawthorne's idea of Nature being in sympathy with human beings is a basic tenet of Romantic thought. He depicts Nature as beauty unspoiled by human beings, which is relevant to Kate Soper's definition of "shallow nature" in her famous book What is Nature?. Hawthorne desires communion with Nature, yet he seeks to transcend it as this paper will prove his ambivalent attitude towards the natural world.

Hester, the central character in Hawthorne's masterpiece, is a pastoral heroine. She resists the strictures forced upon her by the Puritan society and triumphs over them. Though she is made a physical representation of sin to all townspeople, from the onset of the novel she emerges from the prison in full self-assurance and pride. She "repell[s] [the beadle], by an action marked with natural dignity and force of character" (47). In front of the whole townspeople, she wears "yet a haughty smile, and a glance that wouldn't be abashed" (47). When demanded and cajoled to name her fellow sinner, she refuses to reveal her secret and "gr[ows] pale whenever it struggle[s] out of her heart, like a serpent from its holes" (72). The symbolically depicted struggle of the serpent, a kind of species usually "connected with knowledge and wisdom", is an attempt to achieve redemption on the part of Hester 


\section{Amany Abdullah Abdel-Aziz El-Diasty}

(Ferber186). Being in the arms of Nature, Hester gains wisdom. Hawthorne meticulously chooses the serpent, an ecological element, to represent the evil side of nature in correspondence with the viciously grim principles of the Puritan culture. At the same time he shows that Nature identifies itself with the anguish stirring in Hester's unconscious. It supplies ethical and moral insights to Hester's dilemma. In this manner, Hawthorne approaches Nature in at least two different ways: Nature as sympathetic with the suffering of human beings, and Nature as autonomous, revolting against the contradictions of the Puritan Culture.

In spite of the scarlet letter A on her bosom, Hester does not think of her guilt the same way her community does. In the eyes of the Puritan culture, she violates the civil law by committing a crime, yet in the eyes of Nature, she is not committing a crime. Fulfilling her conscious desire with the minister and finishing her seven-year-term of imprisonment, Hester is released but she does not flee Boston. The astonished narrator wonders at her decision: "What she compel[s] herself to believe....as her motive for continuing a resident of New England ... was half a truth, and half a self-delusion" (72). Then the narrator answers this query, revealing the inner thoughts of Hester saying:

$[\mathrm{H}]$ ere should be the scene of her earthly punishment; and so...the torture of her daily shame [will] at length purge her soul, and work out another purity than that which she ha[s] lost; more saint-like, because the result of martyrdom (Hawthorne72).

Though Hester could have fled the town that witnessed her sin and her seven-year punishment, she voluntarily and unexpectedly decides to continue her life with her daughter in Boston. Yet, she makes a spatial movement of pastoralism from Culture to Nature. The concept of pastoral, Daichi Sugai states, "lies between civilization and the wilderness". He adds, it is "an excessively romantic mode" (112). An outcast and a living symbol of women frailty and sinful passion, Hester settles in an abandoned cottage at the edge of the town beside the seashore. In this sense, Hawthorne uses the pastoral as a vehicle to highlight the complex contradictions in his puritan society in an attempt to resolve the tension between Nature/Culture.

A pastoral heroine, Hester cherishes an intermediate landscape somewhere between the refinement of civilization and the rawness of the 
wilderness. She takes a residence on the outskirts of Boston, between the forest and the Puritan authorities. Leo Marx formulates his idea about the pastoral as "a liminal figure [who] moves back and forth across the borderland between civilization and nature" (43). She cuts off herself and her daughter, Pearl, from both of the things that might sustain her. Taking a different path of repentance, Hester considers her voluntary stay in the same place that witnesses her guilt as a source of purging her out of the guilt she has committed and regaining of "the purity [...] she has lost" (72). She isolates herself near the woods and escapes the many judging stares and prying eyes of the townspeople. She wants to separate herself psychologically from the grim Puritan culture. She prefers to lead a primitive life. She enters a domain about which she knows nothing. It is a world based on land as the means of livelihood, with no community ties. She has no relatives already in that place and she cannot befriend any of the Puritan residents back there who mostly scorn her. In such a manner, she is away from the tightening shackles of Puritan Culture.

In her article "Passion and Authority," Nina Baym mentions that "Hester's lonely path, taken less out of conscious decision than out of temperamental necessity, is that of refusing to believe herself evil" (221). Hester denies the accusation of being an evil woman and attempts to rebuild herself in the intermediate place in which she chooses to settle. She cultivates the garden attached to her cottage. Gardening the space overlooking her cottage, which is "a kind of ecological vacuum" (Pollan 70), signifies building herself once again through gaining moral, spiritual and economic pleasure. Since she has a "taste for the gorgeously beautiful", she supports herself and her daughter through her skill as a seamstress (Hawthorne 75). Fellow women need her to make fantastic embroideries for them. In this sense, Hester stands as an effective mediator between the realm of the organized society and that of nature. Living in the arms of nature, Hester learns how to make creative use of all the resources available to further life force, no matter what conditions she finds herself and her daughter in. Hawthorne sarcastically delineates the contradictions of the Puritan townspeople who, though in great demand for Hester's skill of embroidery which is seen "on the ruff of the Governor, on the scarf of military men, and on the band of the minister, on the baby's little cap" (74), refuse to allow Hester embroider the white veil of the brides as if she would contaminate the latter's purity were she to do so. She sustains herself and achieves the honorable gain of moral responsibility as a human being that connects her with life force itself. 
Despite finding domestic happiness and spiritual solace in her daughter and despite busying herself with her skill in needlework, Hester is never free from the mental burden of her sin. Instead of bewailing her lost purity, she plans to create benevolent things for herself. She makes a new identity for herself. In Hawthorne's words: "[i]t could only be a genuine regard for virtue that had brought back the poor wanderer to its paths" (145). Taking an unusually different path of repentance, the pastoral heroine serves the poor and the needy in the community. She "bestow[s] all her superfluous means in charity" (75). She seeks out those "less miserable than herself" to offer charity and also "making coarse garments for the poor" (Hawthorne 75). She has been so helpful to the sick and so comfortable to the afflicted. Eventually, she manages to feed many Boston citizens, clothes them with her embroidery and becomes an accepted contributing citizen of Boston. By acting passionately and benevolently, the pastoral heroine corrects the flaw ingrained in the grim Puritan culture. Bearing her shame, despair and sorrow courageously and with great dignity, Hester gains wisdom and deserves everyone's respect.

In "her earthly punishment" (Hawthorne 72), Hester has been humanized. Departing from the feminine natural concerns of the heart like love, affection and friends, Hester creates a personal impression of "marble coldness [...] alone, and hopeless of retrieving her position... she cast away the fragments of a broken chain" (148). Her breathtaking beauty, pleasant warmth and considerable charm which she once showed have been substituted by severity and coldness. Yet, she deserves our appreciation and respect since she pays her dues first and asks her husband, Dimmesdale's physician, to release her from the promise of silence. With the passing of time, the Boston townspeople attribute Hester's scarlet A, previously the emblem of her shame, to mean "Able; so strong [is] Hester Prynne, with a woman's strength" (146). In her own way, she becomes newly-empowered and respectfully avoided. Disregarding the cultural-framework surrounding her, the pastoral heroine creates her own ethical and moral path in the Puritan society through starting a new life in a fresh green landscape. Hester is a pastoral heroine as she "appears to epitomize the virtues of a simple unworldly life disengaged from civilization and lives ...close to nature" (43). Hawthorne represents a code of ethics throughout the text.

Hawthorne makes ironic remarks about the hypocrisy of the Puritan Culture. The magnificent mansion of the "grave old Puritan ruler" (93), gorgeously furnished, is set in sharp contrast to the poor 
accommodation of the whole townspeople. Hearing that certain influential townsmen feel that Pearl, the "elfish" child and product of sin, should be taken from her, Hester goes with Pearl to the mansion of Governor Bellingham, the man who holds her fate in his hands, pleading him for her right to keep the custody of her little Pearl. Everything is quite exaggerated in that fortress of Puritan rule. Yet, the third-personnarrator notes that these rigid people neglect their garden: "But the proprietor appeared already to have relinquished, as hopeless, the effort to perpetuate on this side of the Atlantic, in a hard soil and amid the close struggle for subsistence, the native English taste for ornamental gardening" (Hawthorne 96). They disregard gardens as they symbolize "erotic sensual life without [...] explicit mapping" (Ferber 83). However, "there were a few rose-bushes [...] and a number of apple-trees" in the mansion garden (Hawthorne 96), a warning and an indication that there is a slight ray of hope of repentance after committing earthly desires. The narrator refers to the idea that first Puritan settlers planted the basics of the Puritan tenets through planting lots of apple-trees and few roses. It is worth noting that the name of Hester's daughter, Pearl, is not haphazardly chosen. Pearl is a precious natural stone and it indicates the very precious price her mother has paid to have her.

Boston's Puritan society of the mid-1660s fears the nearby forest with its "passes of the dark" (Hawthorne 71). Believing that "the Black Man [...] haunts the forest" (69), and that the witches do the devil's work there, the Boston townspeople are warned to stay in that sinful place. Leaving Governor Bellingham's mansion, Hester is approached by his witch sister named Mistress Hibbins who invites Hester to a midnight meeting of witches in the forest. Hester refuses to accompany her, indicating that she would have gone with the Black Man except for her daughter. Though some ecocritical thinkers represent nature as inherently good (Gandy 13), a great deal of ecocritical work these days engages with a far wider set of representational strategies of the nonhuman world. In Scarlet Letter, the Puritans believe that the forest is a secluded location within which lie the powers of darkness. However, Hawthorn, at one time, designates it as a place of truth, freedom and secrecy. He does not tell us explicitly where the adultery takes place in the text. Only does Mistress Hibbins, the soothsayer, refer to the veneer respectability and piety of the minister; she alludes to Hester her sinful act in the forest: Look at that "divine man! [...] he really looks! Who now [...] would think [...] he [...] take[s] an airing in the forest" (Hawthorne 220-21). Mistress Hibbins' last phrase is a symbolic reference to Dimmesdale's 
concealed sin with Hester in the woods, which reveals a complex contradiction in the representative of the Puritan culture.

At the same time, Hawthorne lets the lovers celebrate their unbridled emotions in the arms of Nature irrespective of their consequences. In their recent happenstance in the forest, they reawaken their passion. Communion with Nature enhances warmth of their hearts. Hester's true passionate nature is released once again. She is willing to elope with Dimmesdale as she speaks with him in an attempt to fulfill her latest impulse. She convinces him to flee back to Europe with little Pearl and form a family. Their reunion is considered a sin according to the Puritan tenets, yet it is not necessarily considered so by the standards of the "wild heathen Nature of the forest" (Hawthorne 186) since the latter is so sympathetic with the two lovers as it is "never subjugated by human law, nor illumined by higher truth (186). Instead of becoming hostile and inimical to the sinners, Nature befriends the sad lovers. The narrator goes on telling the readers: "Love [...] must always create a sunshine filling the heart so full of radiance, that it overflows upon the outward world" (186-87). Hawthorne utilizes lots of natural elements to correlate the lovers' inner state of mind; aroused passion brings ecstatic sunshine. He links their interactions with the natural world through image-making. Nature is personified. When Hester approaches the forest, Pearl notices that sunlight avoided her mother because she was wearing the scarlet letter, a sign of impurity according to the Puritan tenets. It is as if nature abhors that emblem, which indicates the unjust Puritan culture, thus eschewing Hester.

Some of Hawthorne's description of nature aids in the telling of a moral ethical nature sympathizing with and assimilating to the cruelty of the 17th century Puritan culture against Hester. The upshot of Hester's radical change results in immense psychic dislocation and loneliness. She is isolated and alienated from the society; the townswomen shun Hester and mock at her whenever she goes back and forth her cottage. The narrator remarks that "in the same circle of seclusion from human society" stand Hester and her daughter (85). Worst still, children fling mud at them. Yet, the woman with her daughter feels secure, centered and in control of her life. Hester is surrounded by Nature in its pure state. Although she is banished and considered as an outcast by the townspeople, she is approved in the ecological surroundings. 
Witnessing the immeasurable misery the minister bears at the hands of her vengeful husband, Hester tries to find Dimmesdale in the forest to disclose the identity of his physician as her husband. Here, Hawthorne sets the scene and makes the basics for that setting as he utilizes much natural imagery to indicate the lovers' inner thoughts and hidden intentions: "[W]ith an unexpressed consent, they glide back into the shadow of the woods" (174). Hester, then, appears and "[sits] down on the heap of moss" (174). The moss, one of Nature's weaklings, provides Hester with comfort for her past hard times. Instead of shunning the woods as any Puritan would do, Hawthorne lets Hester make it her holly place. She claims to Dimmesdale that their love is a saintly and sacred one: "What we did had a consecration of its own. We felt it so! We said so to each other! Hast thou forgotten it?" (178). The lovers sit down

[o]n the mossy trunk of the fallen tree...The forest [is] obscure around them, and creak[s] with a blast that was passing through it. The boughs [are] tossing heavily about their heads; while one solemn old tree groan[s] dolefully to another (Hawthorne 179).

Hawthorne's onomatopoeic language projects an ecological awareness and he does employ nature imagery. Nature, gloomy around the two lovers, is personified as a human being painfully tormented and agonized while recounting the lovers' woeful story. It assimilates their sorrowful spirits. Nature is given feelings; it is humanized. Hawthorne celebrates communion with Nature.

Nature shows the compassion and sympathy that the human world lacks, a basic tenet of Romantic thought. For example, the solemn old tree is a metaphor of the deeply-ingrained anguish of the revered minister because of his concealed guilt. These forces of Nature, while sympathizing with the lovers, are compelled to foreshadow an impending evil and a looming danger. The ominous gloomy tone apparent in Hawthorne's choice of echo words like "blast," "obscure," "creak" and "groan," prepares the reader for the characters' expected future. The narrator goes on narrating that "all these giant trees and boulders of granite seem [...] intent on making a mystery of the course of this small brook; fearing [...] that [...] it should whisper tales out of the heart of the old forest whence it flows, or mirrors its revelations on the smooth surface of the pool" (Hawthorne170).

Nature, here, holds some mysterious and universal meanings. Everything in Nature seems to be whispering the lovers' melancholy 


\section{Amany Abdullah Abdel-Aziz El-Diasty}

story. Ecological surroundings are alive holding the lovers secret; they listen to Hester and Dimmesdale' illicit conversation, witnessing and celebrating their reunion. Even the "babbl[ing] streamlet" remains soothing, but melancholy, like the voice of a young child that does not know "how to be merry among sad acquaintance and events of somber hue" (Hawthorne 170). The streamlet is personified and is given a human attribute which is chatting in sympathy with the lovers' sad story. The use of streamlet simile that resembles the voice of an unhappy child unused to merriment considerably enhances the sympathy of Nature. The brook is also personified through acquiring a human being attribute by Pearl; she calls it "O brook! O foolish and tiresome little brook" (170). Though we cannot hear Nature's mingled sounds, the entire sound that the natural elements produce is a perfect harmony.

Since animal relationship with Nature has been an object of ecocriticism's interest (Glotfelty xxiii), animal imagery which is part of ecocriticism's techniques is used to enhance the connection between Pearl as a product of nature and Nature itself. Animals and plants, regarded as "concrete classifiers" (qtd in Strauss 142), serve to convey the idea that Nature is humanized through sympathizing with the harshly treated Hester and Pearl. Hawthorne widens the scope of his keen observation on nature. The narrator recounts:

A pigeon, alone on a low branch, allow[s] Pearl to come beneath, and utter[s] a sound as much of greeting as alarm. A squirrel, from the lofty depths of his domestic tree, chattered... at the child and flung down a nut upon her head (Hawthorne 188).

Nature, with its elements, welcomes the strutting little child. A pigeon, the gentle bird of love, is personified as a human being knowing Pear and greeting her. In the same manner, a squirrel makes rapid speechlike sounds and presents her something to eat. Even a fox which usually stands for cunning, though alarmed from his nap by Pearl's footsteps, seems docile and harmless. Hawthorne uses a language that is ecologically symbolic. He exaggerates the maternal welcome Pearl receives from the ecological elements to the astonishment of the narrator who recounts that a wolf "offered his savage head to be patted by her hand" (188).

Even the wolf which is always ascribed the epithets 'ferocious' and 'hunger-starved', looks rather full and offers Pearl a kind of merrymaking. 
Flowers and plants know the child of nature and they whisper into her ear as she passes. The narrator writes: "The truth seems to be...that the mother-forest, and these wild things which it nourished, all recognized a kindred wildness in the human child" (188). Holding a different attitude towards Pearl, the sunshine escorts the latter who is "a product of Nature"; it follows her wherever she goes, "quiver[ing] to and fro" (187). Like her mother, though Pearl is spurned by the other Puritan children who fling mud at her, she is highly approved and overwhelmingly welcomed by the wild untamed land of the forest.

Though traditionally dark, wild and untamed, Nature remains 'maternal and feminine' in Scarlet Letter. Hawthorne uses many symbols of Nature and places them in contrast with the stern Puritan Culture during Hester and Dimmesdale's intimate talk. Casting off the scarlet letter, a symbol of the Puritan law, and unpinning the formal cap she puts on her hair, Hester is renovated from a desolate woman of "marble coldness" into a passionate lover full of femininity, expressing her true love for Dimmesdale. Immediately, for the sake of encouraging Hester in her actions, Nature is transformed through a "burst the sunshine, pouring a very flood into the obscure forest, gladdening each green leaf, transmuting the yellow fallen ones to gold, and gleaming adown the gray trunks of the solemn trees (Hawthorne 186). It is worth mentioning that "[W]estern culture has long framed nature in feminine terms while women are framed as somehow closer to nature and as the embodiment of nature" (qtd in Yates 2). Hawthorne, the green writer, employs Nature to support Hester in her conduct. Heaven smiles seeing the reunion of the passionate lovers. Heaven, an element of nature, is personified and given feelings as if it approves what Hester does. Even a green leaf is happy for the lovers' reunion. Even a dry fallen leaf is transformed into a lustrous gold one. Hester, then, heaves a deep sigh of relief that releases both lovers of their shame and guilt of soul. In a sense, the feminization of nature in Scarlet Letter sets the natural world in counterpoise to the patriarchal Puritan culture that is the object of Hawthorne's critique.

Nevertheless, Culture/Nature dichotomy is being apparent in the aftermath of the forest happenstance. After that intimate meeting, Dimmesdale, Hester, and Pearl go on their business next morning as if nothing had taken place the day before. To Hester's astonishment, the minister "seems so remote from her own sphere, and utterly beyond her reach....She [thinks] of the dim forest, with its little dell of solitude, and love, and anguish" (Hawthorne 219). She remembers how profoundly 


\section{Amany Abdullah Abdel-Aziz El-Diasty}

they have shared their intimate moments together with "the melancholy murmur of the brook" (219). She painfully asks herself "[is] this the man? She hardly [knows] him now (219)!" Dimmesdale is to deliver the Election Sermon on the Procession and he does it so eloquently that one feels that it is angelically inspired. Hester is amazed at the huge discrepancy between her connection with Dimmesdale the day before in the dark beautiful forest and his eminence now in the light of the day among his townsmen. Here, appears the complex contradictions in Dimmesdales' inner self shown to Hester plainly the day before in the forest and his social hypocritical self at the marketplace among the townspeople. While Hester and Dimmesdale are not allowed to know each other in Boston's streets according to the Puritan standards, they have already met and intimately talked among the overwhelmingly ecological surroundings. They communed with Nature. The dim forest here is a place of unspoiled beauty where people reveal their inner thoughts and uncover their true concealed personalities.

In examining the psychological depths of a sinful relationship between a minister and his female parishioner who becomes a pastoral heroine, Hawthorne delves deeply into the mysteries of their human minds. Though his Puritan society erroneously estimates him highly, Dimmesdale is Hester's fellow sinner. His community deems him

[a] miracle of holiness. They fanc[y] him the mouth-piece of Heaven's messages of wisdom, and rebuke, and love. They worship the very ground on which he trod (129).

Though he knows what is right, he cannot acknowledge his sin in public. Like all human beings, he has to pay for the consequences of his secretly sinful deed. Though Dimmesdale fails to live up to the expectations required of him as a minister, all Puritan parishioners turn to him for guidance and wisdom. Because he has nobody to turn to for advice, he buries himself beneath sin and secrecy. He suppresses his shame of hidden guilt which results in an inability to connect with society and a motion of constantly "putting his hand over his heart". Though Dimmesdale "with every successive Sabbath, his cheek was paler and thinner, and his voice more tremulous than before" (109), he prepares himself to die and needs no medicine.

As a representative of the Puritan culture, Dimmesdale believes in the power of the wild heathen Nature. He is conscious of his unique 
destiny that will correspond what he has committed. His selfconsciousness, one of the key elements of Romanticism, is alert. Hawthorne lets Dimmesdale "question with himself whether the grass would ever grow on [his grave] because an accursed thing must there be buried" (129). Here comes the lurking ambivalence in Hawthorne's attitude towards Nature/Culture dichotomy. While alone, Dimmesdale realizes the self-articulatory Nature that reacts against man's wrong deeds. While in communion with Hester, he notices that all natural surroundings work in harmony. Dimmesdale's mental and spiritual suffering manifests itself in his physique. Although the minister keeps presenting inspiring eloquent sermons, his deteriorating health signifies his inner conflict. If he had followed the norms of the Puritan society, he could have confessed his sin of adultery. Yet, he chooses to hide the fact that he is Pearl's father, an inherent contradiction in the Puritan Culture. The minister fails to comply with the Puritan tenets. From the beginning of the Romance, he hides behind Hester's silence. However, he is conscious of his guilt. In Hester's appealing to Dimmesdale for help in the mansion of Bellingham, Hawthorne shows how Dimmesdale is a soul in torment:

He looked now more care-worn and emaciated than as we described him at the scene of Hester's public ignominy; and whether it was his failing health, or whatever the cause might be, his large dark eyes had a world of pain in their troubled and melancholy depth. (102)

Dimmesdale' s obvious nervousness, strange earnestness, and weakened condition while Hester appeals to him to speak for her right to keep her daughter suggests how terribly the man has been suffering from his hidden sin. Throughout the romance, Hawthorne draws the readers' attention to Dimmesdale's deteriorating health. He is worn out of his dual personal nature: his inner self and his social self. Being a sinner, his conscience is pricked with guilt. Fearing public exposure, Dimmesdale in his private room flogs himself, fasts and keeps vigils in an attempt to soothe his agonized and tormented soul and mollify his sense of guilt. The enormously heavy weight of Dimmesdale's unrevealed guilt of his deed brings out his decline. Hawthorne probes into Dimmesdale's conscience revealing his mental anguish and painful inner battle which are manifested in his physical appearance.

One thread that connects the ecocritical reading of Hawthorne's romance to Lacanian psychological analysis is language since language is "a model for the understanding of all forms of social and cultural life" 


\section{Amany Abdullah Abdel-Aziz El-Diasty}

(Suprenant 206). Several binary oppositions are put to the fore in the Scaffold scene, which show Hawthorne's stance towards Culture/Nature dichotomy. In his shallow attempt to free himself of his secret sin in the middle of the night, Dimmesdale climbs the steps of the scaffold where Hester, his fellow sinner, was punished seven years ago. Attempting redemption while fearing public scorn, Dimmesdale amounts the scaffold at the secrecy of mid night hours. Soon after, Hester and Pearl join him on the scaffold at midnight for the first time while the townspeople are unaware of the action. Twice Pearl asks him if he will amount the scaffold with them at noon next day so that all townspeople can see them together, the minister retorts that he will stand with them on "the great judgment day" (139).

Nature in Hawthorne's Scarlet Letter is not just a backdrop, a marginalized or a silenced entity; rather it is self-articulatory and answers back what the Puritan culture holds. It is a real, autonomous entity, having its own repercussions in the social realm, which is the major function of ecocriticism. Fearing confession and public exposure, Dimmesdale emphasizes that "the daylight of this world shall not see our meeting" (139). At these moments the natural world reacts to Dimmesdale's hypocritical speech and there comes a revealing light from heaven; a strange light in the sky illuminates the scaffold and its surroundings. The narrator indicates:

[A] light gleam[s] far and wide over all muffled sky. It [is] doubtless caused by one of those meteors... in the vacant regions of the atmosphere. So powerful [is] is radiance, that it thoroughly illuminate[s] the dense medium of cloud betwixt the sky and [the] earth. The great vault brightened, like the dome of an immense lamp. It shows the familiar scene of the street, with the distinctness of mid-day (139).

Hawthorne lets a natural element, a meteor, answers back to what Dimmesdale is telling the little child; it forebodes what is to come. This scene holds a paradox; the image of light emerging from darkness is significant. He tells the child the truth and truth gives us light to see and understand the fake nature of the Puritan culture. Not only does Dimmesdale fail as a lover, but he also fails as a father by denying his daughter, and allowing her to live as an outcast. For the first time, they stand together "in the noon of that strange and solemn splendour, as if it were the light that is to reveal all secrets, and the daybreak that shall unite 
all who belong to one another" (139). One finds the binary oppositions in this scene in sky/earth, dark/light, daybreak/night, dense/vacant, muffled/powerful, public/private. The indicated revealing light at mid night hours signifies the epiphany and revelation of the human secrets. This scene gives a moral interpretation to what happens in the fake Puritan world with its complex contradictions.

In their happenstance in the forest when Hester asked him whether his good deeds bring him peace of mind, Dimmesdale replies, "there is no substance in it! It is cold and dead, and can do nothing for me! Of penance, I have had enough! Of penitence, there has been none" (175). His outward hypocrisy and his unconfessed sin prevent him from gaining the rewards of his fasting, keeping vigils and flogging himself. His hidden sin leads to overpowering guilt and results in eventual death. After talking with Hester in the forest, Dimmesdale feels compelled to forsake the holy for the wild. Hawthorne examines the nature of the spiritual battle warring within the minister:" $[\mathrm{H}]$ is inner man gave him other evidences[sic] of a revolution in the sphere of thought and feeling" (199). Having no one with whom he can unburden his tormented mind, Dimmesdale talks to himself: "I am not the man for whom you take me" (199)! He attributes his sweeping change to his recent meeting with Hester in the forest, adding that he leaves his true passionate self there "withdrawn into a secret dell, by a mossy tree-trunk, and near a melancholy brook" (199), the sympathetic witnesses of his secret meeting. He refers to his dual personal nature which comprises his social self and his inner self. Deep inside, he knows that running away with Hester and Pearl will not remove the stain of his guilt. After delivering his most spiritually moving sermon, he dies in front of the entire townspeople.

Not strong enough to bear the hypocrisy of showing one face to the world while knowing another, Dimmesdale finally "[tears] away the ministerial band from before his breast. It [is] revealed! [...]. For an instant the gaze of the horror-stricken multitude [is] concentrated on the ghastly miracle" (234). Sensing failure of the escape plan, Hester realizes the huge discrepancy between his public and private behaviour. Hawthorne ironically refers to the dichotomy of the Puritan society: "The sainted minister in the church! The woman of the scarlet letter in the marketplace" (226)! Her inner self feels even worse at the idea that she must be deluded. Hawthorne then describes the woman's inner feelings and her internal disappointment about Dimmesdale: "[M] uch [has been] 


\section{Amany Abdullah Abdel-Aziz El-Diasty}

there in Hester, that she could scarcely forgive him [...] for being able to withdraw himself from this material world; while she grope[s] darkly, and stretche[s] forth her cold hands, and [finds] him not (219)". Her alert conscience tells her that there "could be no real bond betwixt the clergyman and herself" (219). Feeling an overshadowing doom, Hester is freezing. Her frustration is indicated through her empty chilled hands.

Though the pastoral heroine is about to fulfil her spiritual impulse through uniting with Dimmesdale, she is now sure that they will never be reunited. Dimmesdale could have seized the chance and eloped with her and their daughter and lived together as a normal happy family, yet his connection with the Puritan culture is too resilient to be unchained. After his public confession, Dimmesdale dies, followed by the death of revengeful Chillingworth leaving much wealth for Pearl. Hester and Pearl leave for Europe. Many years after their departure, Hester, wearing the same scarlet letter, returns to Boston to live in the same old cottage. Leaving the reader undecided of the reason for Hester's arrival, Hawthorne puts it: "there [i]s a more real life for Hester Prynne, here, in New England, than in that unknown region where Pearl has found a home [.... She return [s] [...] and resume [s] of her own free will" (240). Then he adds that Hester "resume[s] the symbol of which we have related so dark a tale" (240). The novel's ending bears the element of ambivalence in the author's stance towards the Culture/Nature dichotomy.

The Scarlet Letter presents Hawthorne's attack on the grim culture of 17th century American Puritans through the perspective of a 19th century New Englander. Here, Hawthorne proves to be a "green writer" whose language projects an ecological awareness; he does employ natural imagery in the Scarlet Letter. He struggles to rediscover the natural landscape that his Puritan ancestors once possessed and discarded as a secluded location of secret desires. The text conveys a code of ethics. Hawthorne realizes a more fruitful fashion to live with the land. Within an ecocritical framework, Hawthorne approaches Nature in at least two different ways. He desires communion with Nature, yet he seeks to transcend it. Nature represented in the text is not just a backdrop, or a silenced entity; rather it is self-articulatory and answers back what the Puritan Culture holds. At another time, Hawthorne shows nature as a real, autonomous entity standing outside human culture with only one link. Yet, the feminization of nature sets the natural world in counterpoise to the puritan culture. Whenever the lovers meet, Nature provides a kind of solace for them. Because of his frailty and fear of public scorn and shame, 
the immediate upshot of Dimmesdale's cultural socialization leads to his death. Not only does he fail as a lover, but he also fails as a father by denying his daughter, Pearl, and allowing her to live as an outcast.

In an attempt to resolve the culture/nature dichotomy, Hester, the pastoral heroine, cherishes an intermediate landscape somewhere between the refinement of civilization and the rawness of the wilderness. Hawthorne employs the pastoral as a vehicle to explore the complex contradictions in the Puritan culture. After finishing her seven years of imprisonment, the pastoral experience of Hester's retreat from the tensions of the city of Boston with its grim Puritan culture into the wilderness for raw contact with nature is a social need for her and it does gain her wisdom through solitude, deprivation and suffering. She strives for settling a satisfactory and acceptable resolution between the constraints of society and those of nature. Nature identifies itself with Hester's anguish stirring in her unconscious. It supplies ethical and moral insights to Hester's dilemma.

At the end of the romance, Hester, alone, makes a return home, to Boston, both literally and figuratively. Meanwhile, the pastoral heroine realizes the significance of returning to the place that witnesses her growing wisdom and she resumes living in her cottage in Boston. She is what she had been before, a dignified woman; she remains true to her morals. She has actually gained wisdom through her long years of silent suffering, and through her physical connection with and awareness of natural surroundings. That is why she returns to comfort the wounded and to soothe the sinned. She cannot flee her ethical commitments to the Puritan society. The grim Puritan society, which once scorned her, has now regarded her as an emblem of social virtue. Binding the interdisciplinary nature of the ecocritical approach together with Lacanian psychology, this paper reveals Hawthorne's lurking ambivalence towards Culture/Nature dichotomy which could be traced to his stance. This has led to fruitful insights concerning his attitude of the communion with Nature and transcendence of Nature. While his treatment of the subject shows a celebratory attitude of Nature and the natural surrounding over Culture, the romance's ending bears an ambivalence of his stance towards Nature/Culture.

Exploring the interdisciplinary nature of Ecocriticism to the pastoral mode permits a reconsideration of nature/culture relationship. Hawthorne employs his pastoral heroine who attempts to resolve the root tensions between culture and nature by living in the borderline between 


\section{Amany Abdullah Abdel-Aziz El-Diasty}

them, gaining wisdom through her long years of solitude. Hester's portrayal is associated with a celebratory attitude towards Nature with all its patterns of nonhuman world. Through the pastoral experience of Hawthorne's heroine, he rediscovers the natural landscape his ancestors once possessed and discarded as a secluded location of secret desires and moral absence, gaining some moral beliefs and realizing a more fruitful fashion to live with the land. One can also say that he wishes to uphold a relationship between human beings and the natural world through revitalizing man's way of connecting with nature. The paper shows that though Hawthorne mostly elevates Nature as the essential embodiment of ethics, wisdom, and values, he seeks to promote a reconsidering of one's beliefs and one's vision of Nature for a sound awareness and essential unity of life. 


\section{Works Cited}

Baym, Nina. "Passion and Authority in the Scarlet Letter." The New England Quarterly, vol. 43, no.2,1970, pp. 209-30.

Bull, Lawrence. The Future of environmental Criticism: Environmental Crisis and Literary Imagination. Oxford: Blackwell, 2005.

Ferber, Michael. A Dictionary of Literary Symbols. Cambridge UP,1999. Print.

Gandy, Mathew. "Visions of Darkness: The Representation of Nature in the Films of Werner Herzog". Cultural Geography, vol. 3, no.1,1996, pp.1-21.

Glotfelty, Cheryll and Harold Fromm. eds. The Ecocriticism Reader: Landmarks in Literary Ecology. U of Georgia P, 1996.

Howarth, William. "Some Principles of Ecocriticism." The Ecocriticism Reader: Landmarks in Literary Ecology. Cheryll Glotfelty and Harold Fromm. eds. Georgia UP, 1996.

Hawthorne, Nathaniel. The Scarlet Letter (1850). The Modern Library, 2000.

Levi-Strauss, Claude. The Savage Mind. The Garden City Press,1962.

Marx, Leo. "Pastoralism in America." Ideology and Classic American Literature. M. Jehles and S. Bercovitch. eds. Cambridge UP, 1987.

Pollan, Michael. Second Nature: A Gardner's Education. Grove Press, 1999.

Oppermann, Serpil. "Ecocriticism: Natural World in The Literary Viewfinder." Journal of Faculty of Letters, vol. 16, no. 2,1999, pp. 2926.

Ortner, Sherry. "Is Female to Male as Nature is to Culture?" Woman, Culture, and Society. M. Z. Rosaldo \& L. Lamphere. eds. Stanford UP,1974.

Sayre, Gordon. "The Oxymoron of American Pastoralism." Arizona Quarterly: A Journal of American Literature, Culture, and Theory, vol. 69, no. 4, MUSE 2013, pp.1-23.

Soper, Kate. What is Nature?: Culture, Political and the Nonhuman. Blackwell, 2009.

Sugai, Daichi. "Pastoral as Commodity: Brautigan's Reinscription of Hemmingway's Trout Fishing". The Hemingway Review, vol. 36, no. 2, 2017, pp.112-123.

Suprenant, Celine "Freud and Psychoanalysis." Literary Theory and Criticism. Patricia Waugh, ed. Oxford UP, 2006, pp.199-211.

Yates, Michelle. "Recasting Nature as Feminist Space in Mad Max: Fury Road 1." Science Fiction Film\& Televising, vol.10, no.3, 2017.

*This paper follows MLA style of documentation, $8^{\text {th }}$ edition,2017 